\title{
Omkring »Præsident« Topff, Sønderborg
}

\author{
Af A. Thyssen.
}

Først fornylig blev jeg bekendt med stud. mag. Kaj Rolfsen Nissens velskrevne og interessante redegørelse i Sønderjyske Årbøger, 1. halvbind 1965, om problemerne omkring "Præsident" Topff.

Da jeg tilfældigvis selv $\mathrm{i}$ de bevægede novemberdage i 1918 befandt mig i begivenhedernes centrum i Sønderborg som ung søkadet på reservesøofficersskolen, der den 1. oktober 1918 var blevet oprettet $i$ den nordligste af marinekasernens bygninger $i$ Sønderborg, er jeg $\mathrm{i}$ stand til at kunne give nogle supplerende oplysninger til førnævnte redegørelse.

Til nærmere forståelse af foranstående mener jeg at burde oplyse, at mine forældre begge var født i Toftlund sogn. Hele familien var landmænd, men da min far havde lyst til at læse, indtrådte han $\mathrm{i}$ det tyske postvæesen og gjorde bl. a. i mange år tjeneste på Haderslev postkontor, men blev i 1917 forflyttet til Heide i Holsten, hvor han gjorde tjeneste som fung. postdirektør, indtil han ved genforeningen som en del andre dansksindede sønderjyder i tyske embedsmandsstillinger vendte tilbage til Danmark og derefter først blev ansat ved postkontoret i Sønderborg, hvorefter han tilbragte mange gode og lykkelige år som postmester i Skærbæk.

Mens mine forældre boede i Heide, gik jeg på gymnasiet i Meldorf, hvorfra jeg den 4 . oktober 1918 blev indkaldt til marinen i Sønderborg.

Selvom de fleste af os nok var klar over, at krigens afslutning og Tysklands nederlag var nær forestående, gennemgik vi en meget hård skole med både fysisk træning og en omfattende teoretisk oplæring i navigation m. m., og alt forløb tilsyneladende normalt indtil søndag aften den 3 . november 1918 , da de første 
rygter om mytterier i marinen i Kiel nåede kasernen i Sønderborg.

I de følgende dage sporedes stærk nervøsitet blandt officererne, og rygterne voksede, uden at vi fik konkrete oplysninger.

Natten mellem onsdag, den 6. november, og torsdag, den 7. november, blev vi alarmeret kl. 3 og stod opstillet på kasernens gange i ca. to timer, parate til at rykke ud. Man lod os forstå, at man havde fået underretning om, at en krydser med "røde" matroser var på vej fra Kiel til Sønderborg, og at der evt. skulle gøres modstand. Officererne var tilsyneladende stærkt nervøse og rådvilde, men ved 5-tiden om morgenen blev alarmen afblæst igen.

Om formiddagen torsdag den 7 . november gjorde vi normal tjeneste med eksercits m. m., men ved middagstid blev der meddelt os, at tjenesten herefter var suspenderet, og om eftermiddagen foretoges en marchtur uden udrustning og våben til "Fiskerhytten " ved Sønderskoven.

Marchturen blev ledet af næstkommanderende, „Kapitänleutnant zur See" von Augsburg, der forøvrigt havde været med på hjælpekrydseren "Möwe», der camoufleret som neutralt handelsskib $i$ en længere periode havde lavet en frygtelig ravage $i$ Sydatlanten, hvor den havde opbragt og sænket en række handelsskibe, fra hvilket togt den var sluppet hjem igen $\mathbf{i}$ god behold.

Da vi på hjemvejen marcherede over pladsen foran $\gg$ Hotel Alssund ", lagde vi mærke til, at en temmelig ophidset civilperson henvendte sig til von Augsburg, og umiddelbart efter løb det ned langs rækkerne, at et krigsskib, bemandet med røde matroser, var gået til kaj umiddelbart nedenfor skolen, og at det røde flag vajede fra bygningens tårn.

Umiddelbart efter ankomsten til kasernen fik vi sammen med de tilbageværende officerer ordre til at tage opstilling på kasernepladsen omkring et bord, som et øjeblik efter en matros $i$ en flagrende, stribet hospitalsfrakke og med huen uden kokarde bag i nakken (som vi senere fik at vide, skræddersvend Bruno Topff), sprang op på, hvorefter han holdt en tordentale, som han indledte med følgende bombastiske ord: "Nun haben wir die Macht ergriffen, und das Hampelmann (sprællemand) spielen ist vorbei. Wir kommen soeeben von Kiel, wo wir 600 Officiere erschossen 
haben «. Det sidste viste sig dog heldigvis at være pral. Dels havde Topff ikke været med i Kiel, idet han som bekendt dagen forinden havde forladt Marinehospitalet i Sonderborg, hvor han henlå med en alvorlig tuberkulose, og navnlig er det en kendsgerning, at matrosopstanden i Kiel forløb næsten uden ofre. Iflg. autentiske oplysninger skete der kun en episode på slagkrydseren "König", hvor kommandanten og to officerer, da de ved flagmasten nægtede at stryge krigsmarinens flag og hejse det rode flag, blev »niedergemacht « .

Under talen advarede Topff iøvrigt $i$ megel kraftige vendinger mod enhver art af modstand eller hindring mod at gennemføre omvaltningen, idet han truende gjorde os bekendt med, at krydserens kanoner var rettet mod skolens bygning, hvilket forøvrigt var rigtigt, og at der ville blive skudt ved mindste tegn til modstand.

Talen sluttede med, at han udråbte gen Als som selvstændig republik og meddelte, at enhver forbindelse over pontonbroen til fastlandet var afbrudt, og at han havde overtaget styret som præsident over republikken Als.

Derefter måtte de tilbageværende officerer defilere forbi bordet, hvor de måtte lægge deres sabler for fødderne af "Præsident * Topff, noget der selvfølgelig gjorde et stærkt indıryk på os unge, og sikkert må have været den bitreste stund i en tysk søofficers liv.

Af selvfølgelige, velforståelige grunde så vi ikke mere noget til vore officerer, selv om vi, der jo alle var ganske unge, folte os svigtet og ikke anede, hvorledes den videre udvikling ville forlobe, og hvad der ventede os, indelukkede som vi var $i$ »republikken" Als med en skræddersvend som "Præsident".

Hvor nervose officererne var, viser en lille episode, da jeg en aften nogle dage senere gik langs havnen, og en dør i et lille hus pludselig blev âbnet på klem, og en af vore officerer, der tilsyneladende havde genkendt mig. hviskende bad om oplysninger, hvordan det stod til på kasernen.

Vi blev selvfølgelig straks afvæbnet, måtte aflevere vor øvrige udrustning og fik ordre til at pille distinktionerne som kadetter af uniformen og kokarde og huebånd af huen.

Iøvrigt kunne vi færdes frit på kasernen og i Sonderborg by, 


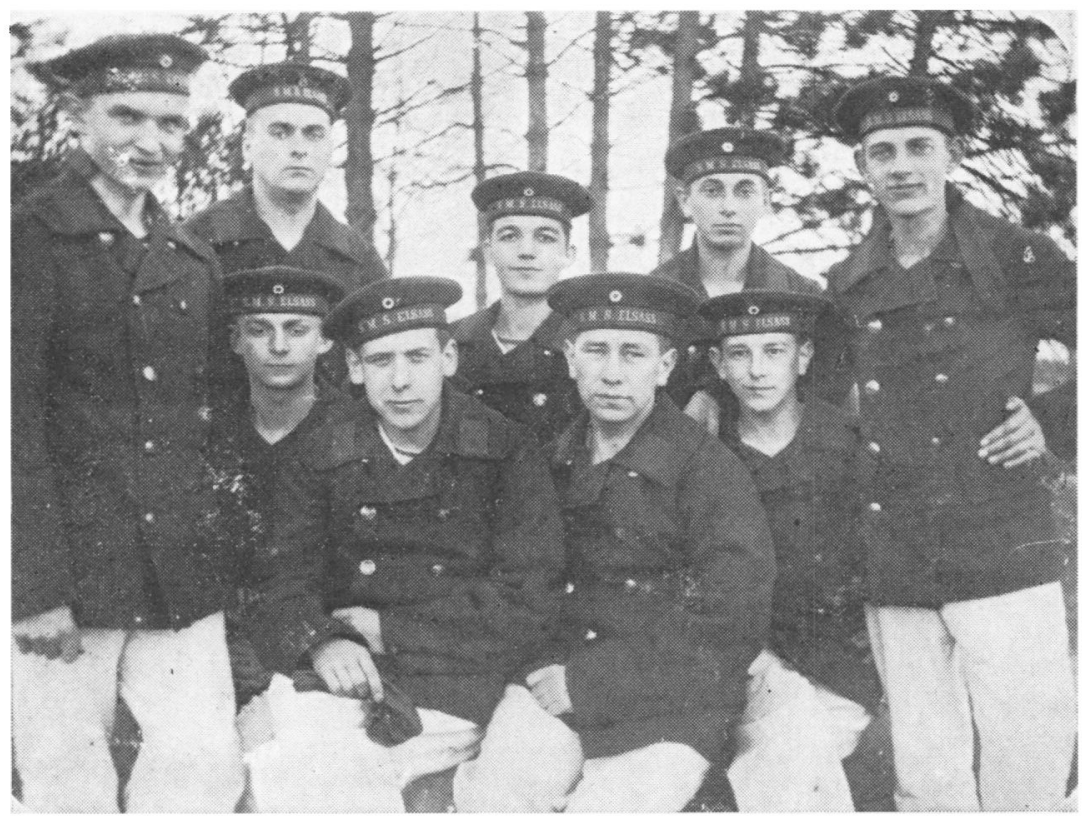

På billedet ses 3. deling af 2. søkadetkompagni med forfatteren yderst til højre.

forudsat at vi for at undgå forulempelser havde noget rødt på uniformen. Heldigvis var en af kammeraterne $i$ vor deling i besiddelse af et par røde badebukser, som han of rede på revolutionens alter ved at dele den ud i smålapper, som vi bar i knaphullet. Som et minde om de bevægede novemberdage i 1918 i Sønderborg gemmer jeg endnu denne lille, røde lap.

I de følgende dage så vi mange gange "Præsident " Topff fare ud og ind ad kaserneporten i landrådens store gamle bil med et stort, rødt flag på køleren og to matroser med opplantede bajonetter på vognens trinbræt.

Tidligt mandag morgen, den 11. november, blev vi pludselig purret ud og fik besked om, at vi ville blive ledsaget over pontonbroen og kunne rejse hjem.

Hjemsendelsespapirer eller orlovsbevis modtog vi selvfølgelig ikke, men heldigvis havde vor delingsfører, en ældre, meget rolig underofficer, der forøvrigt ikke havde tabt hovedet, men på en særdeles god måde havde taget sig af os unge indtil vor afrejse, 
da begivenhederne på kasernen begyndte at tage fart, på kontoret forsynet sig med en bunke blanketter til orlovssedler, som han havde delt ud blandt os til evt. senere brug.

Som kuriosum kan jeg anføre, at jeg ved denne lejlighed eneste gang i mit lange liv har gjort mig skyldig i dokumentfalsk, idet en af kammeraterne $i$ vor deling udfyldte blanketterne med tilladelse til orlov indtil videre til vore respektive hjembyer, medens det var min opgave at påtegne blanketterne: Der Arbeiter und Soldatenrat, Topff «, hvis navn jeg skrev på adskillige orlovsblanketter.

Under hjemrejsen blev jeg i Tønder, hvor jeg skulle skifte, af bevæbnede matroser fort til et vagtlokale, hvor jeg med nogen bæven fremviste mit falske orlovsbevis, men da underskriften var de rette magthaveres, og min røde lap $i$ knaphullet viste, at jeg havde den rette kulør, fik jeg et nyt stempel med en denne gang formentlig xgte underskrift og kunne rejse videre. Det samme gentog sig forøvrigt i Husum, og da jeg henimod aften ankom til Heide.

Desværre er jeg ikke mere $i$ besiddelse af dokumentet, idet jeg måtte aflevere det $\mathrm{i}$ Heide for at få ernæringskort.

Få dage efter sad jeg atter på skolebænken i Meldorf.

Jeg er herefter formentlig den eneste, i hvert fald fra vor landsdel, der personlig har hørt Bruno Topff proklamere $\gg$ Republikken Als « og udnævne sig selv til "Præsident ", idet der næppe har været civile til stede under begivenhederne på kasernepladsen i Sønderborg torsdag eftermiddag, den 7. november 1918, mellem kl. 16 og 17, og idet jeg var den eneste af officerer og menige, der var hjemmehørende i Sønderjylland.

Jeg kan endelig anføre, at jeg bestemt mener at kunne huske, at jeg engang i begyndelsen af 1920erne på kirkegården i Sønderborg har set Topff's gravsted, forsynet med en lille, uanselig grå gravplade, men graven er formentlig forlængst sløjfet.

Må jeg så til slut tilføje, at jeg, da jeg hine grå novemberdage 1918 oplevede begivenhederne omkring "Republikken Als" kortvarige eksistens og dens "Præsident* Topff, næppe ville have drømt om, at jeg godt $2^{1 / 2}$ år efter, at disse begivenheder udspillede sig i Sønderborg, skulle opleve en af de lykkeligste begivenheder i mit liv, at blive dansk student fra Sønderborg Statsskole. 